\title{
Modelling Effects of Tariff Liberalisation on India's Key Export Sectors: Analysis of EU-India Free Trade Agreement
}

\author{
Sangeeta Khorana \\ Badri G. Narayanan
}

\begin{abstract}
Trade agreements are increasingly being negotiated between developed and emerging economy partners. An example is the EU-India Free Trade Agreement (FTA) for which negotiations began in 2007. There has been a debate on the potential effects of the proposed FTA and how this can impact on India's key export sectors. Our study addresses this aspect from a global computable general equilibrium (CGE) modelling perspective. Using the Global Trade Analysis Project (GTAP) framework, we analyse trade and welfare impacts of the proposed FTA between the EU and India. Two scenarios are modelled: first, complete and immediate elimination of tariff on all goods traded and second, selective tariff elimination on textiles, wearing apparel and leather goods-products in which India has a comparative advantage. Results under both scenarios show that India enjoys positive welfare effects though there is a possibility of trade diversion. Under scenario 1, India loses due to negative terms of trade (ToT) effect. Under scenario 2, with selective sectoral liberalisation, gains are mainly concentrated in textiles, wearing apparel and leather sectors. There is a positive output effect from change in demand for factors of production suggesting that the proposed FTA could lead to relocation of labour-intensive production to India.
\end{abstract}

Acknowledgements: The authors wish to extend special thanks to David Vanzetti and Lars Nilsson for their valuable comments. We are also grateful for some very useful comments that we received from GTAP 2011 conference participants.

Sangeeta Khorana is at the Bournemouth Business School, Bournemouth University, Dorset BH8 8ER, United Kingdom. She is the corresponding author, email: skhorana@bournemouth. ac.uk; sangeetakhorana@hotmail.co.uk

Badri G. Narayanan is at the School of Environmental and Forestry, University of Washington, Seattle, WA, USA, email: badrig@uw.edu 
Key words: Economic Integration, Forecasting and Simulation, Macroeconomic effects JEL Classification: F15, F47, F62

\section{INTRODUCTION}

India and the EU have been negotiating a bilateral free-trade and investment agreement (BTIA) since June 2007. The proposed agreement aims to be a broad-based trade and investment agreement, which will cover over 95 per cent of tariff lines and also liberalise non-conventional sectors in services and investments, with rules on domestic regulation, competition and government procurement. Talks have been at a standstill for some time and several deadlines have been missed. The negotiating partners propose to renew talks in June 2015 and address unresolved issues on market access. The proposed agreement is ambitious in that it will create one of the world's largest free-trade areascovering 1.8 billion, representing a quarter of the world's people with bilateral trade at over $€ 100$ billion in 2014-15. Further, increasing trade between the EU and India reaffirms the importance of the $\mathrm{EU}$ as India's largest trading partner. Finally, the proposed agreement will not only open markets and further business opportunities for EU firms (European Commission, 2010), but also be a means to further a normative aspiration of the EU to export its preferred model of liberalisation, governance and multilateral regulation (Khorana \& Garcia, 2014).

This article employs computable general equilibrium (CGE) analysis to examine the macroeconomic effects of trade liberalisation through a free-trade agreement (FTA) between the EU and India by focusing on trade, production and welfare effects. We also explore the link between trade creation, factor endowments and the economic size of trading partners and whether an FTA between dissimilar countries can potentially amplify inequalities by impacting on welfare in the partner and third countries. Thus, the article comments on the developmental dimension of the proposed FTA and also on the possible benefits of such an agreement between two unequal partners, in this case, India and the EU, for those sectors in which India has a comparative advantage. Using the example of textiles, wearing apparel and leather goods, which constitute nearly one-third of India's total exports to the EU (Eurostat, 2012), the article analyses the effects of selective liberalisation of sectors in which India has a comparative advantage. The rationale for analysing specific sectors is that studies model potential economic outcomes to analyse the overall economic effects of the FTA between EU and India ${ }^{1}$ (Achterbosch, Kuiper \& Roza, 2008;

\footnotetext{
${ }^{1}$ For an exhaustive discussion on EU-India FTA analysis, see Agence Europe (2007), Decreux and Mitaritonna (2007), Achterbosch et al. (2008), Khorana et al. (2008), Powell (2008), Khorana
} 
Agence Europe, 2007; Decreux \& Mitaritonna, 2007; ECORYS, 2009) with some examining 'deep' versus 'shallow' integration effects (ECORYS, 2009; Gasiorek et al., 2007). None of these analyse the welfare, trade and distributional effects on sectors in which India has a competitive advantage vis-à-vis the EU. The article is organised as follows: The second section presents an overview on economic integration literature highlighting recent studies. The third section analyses goods trade patterns between the EU and India, focusing in particular on trade in textiles, wearing apparel and leather products. The fourth section lists theoretical foundations of the Global Trade Analysis Project (GTAP). The fifth section discusses simulation scenarios and the results. The sixth section concludes with the way forward for FTA talks.

\section{Literature Review}

\subsection{Literature on Regional Integration}

Academic literature primarily focuses on examining 'trade diversion' and 'trade creation' effects of FTAs (Viner, 1950). ${ }^{2}$ In recent years, economists have employed a multitude of approaches to portray regional integration effects. Recent studies find that trade agreements have significantly positive tradeenhancing effects due to tariff reduction. For instance, Wannacott (1990) puts forth the 'hub and spoke' approach suggesting that there is an increased interconnectedness between trading partners. Other economists discuss the 'domino effect' of FTAs and how this provides an impetus to non-participating countries to seek membership to trading agreements (Baldwin, 1993; Baldwin \& Jaimovich, 2012). In terms of welfare analysis, Robinson and Thierfelder (2002) highlight welfare-enhancing potential of trade agreements for member countries and rest of the world. Thus, within extant literature, there is ample evidence on 'building blocks' proposition of trading agreements and how these are stepping stones for future multilateral trade liberalisation (Dent, 2003; Ethier, 1998; Khorana \& Garcia, 2014; Summers, 1991; Wei \& Frankel, 2005). But some researchers, however, put forth the 'stumbling blocks' approach and

and Perdikis (2010), Khorana and Garcia (2013), Khorana and Asthana (2014) and European Commission (2015).

${ }^{2}$ See Meade (1995), Lipsey (1970), Pomfret (1988) and Magee (2016) for an exhaustive economic overview on rationale and determinants of FTAs. Recent debate has concentrated on understanding the effects of FTAs on non-members of FTA countries (Anderson \& Yotov, 2011; Baier \& Bergstrand, 2007; Brown, Deardorff \& Stern, 1994; Dai, Yotov \& Zylkin, 2014; Helpman et al., 2008; Kehoe \& Kehoe, 1994; Magee, 2008). 
argue that regional agreements detract partner countries' efforts to liberalise at the multilateral level (Bhagwati, 1998; Panagariya, 1996, 2000; Srinivasan, 1998). In a similar vein, Bhagwati and Panagariya (1996) propose the 'spaghettibowl' approach and suggest that such arrangements generate complexity and contribute to lack of transparency in the global trading system. Despite unanimity on the effects of trading agreements, there is growing support for FTAs in that these agreements improve access to markets and level playing field, and build alliances for World Trade Organization (WTO) negotiations, though some cast doubts on the benefits of individual FTAs between large economies and smaller ones, and the wisdom of limited agreements (Baldwin, 2002, 2006, 2008, 2011, 2013; Bhagwati \& Panagariya, 1996; Bhagwati, 1998; Khorana \& Garcia, 2013; Khorana et al., 2010; Krugman, 1993; Viner, 1950). However, given that trade agreements have been accepted as a way forward to regional integration, the negotiating countries are facing the challenge of how to maximise their benefits while minimising their costs (Ng \& Yarcia, 2014).

Given that FTAs are increasing between developed and developing countries from different geographical regions, geography is an increasingly relevant issue for discussion. Literature suggests that geographical proximity determines total gains and losses, and that there is high trade dependence and low risk of trade diversion between countries from the same geographical region (Lipsey, 1957; Summers, 1991). Cernat (2003) and Lee and Shin (2006) analyse the impact of geography on FTAs between developing and developed countries and report inconclusive evidence. Baier and Bergstrand (2007) report that trade creation is closely linked with relative factor endowments and the economic size of trading partners suggesting that an agreement between countries with dissimilar market size could potentially amplify inequalities. The World Bank (2000) report substantiates that benefits from FTAs vary with size and the level of development of the partner country. Magee (2003) is of the view that size and locational dissimilarity between developing and developing economies make these countries 'unnatural partners', which adversely impact on partner countries' benefits. Within the framework of 'natural trade partners' hypothesis, Wonnacott and Lutz (1989), Frankel, Stein and Wei $(1995,1998)$ and, more recently, Freund and Ornelas (2010) argue that trade diversion may be less relevant than initially perceived and countries are most likely to experience growth in trade after concluding a trading agreement. The importance of transport costs between countries also finds mention in 'inherent regionalism' theory advocated by Frankel (1997), Frankel, Stein and Wei (1995) and Frankel and Wei (1997). In addition to existing views, Grossman and Helpman (1991), Keller (1998) and Coe and Hoffmaister (1999) highlight that trade through agreements generates productivity links leading to technology transfer and 
diffusion between members. Their findings are congruent with Baldwin's 'domino theory' which suggests that regional agreements trigger countries to lower bilateral import barriers 'like a row of dominoes' to avoid losses from the trade diversion effect in the event of these countries remaining outside the regional agreement (Baldwin, 1995; Baldwin \& Venables, 1995).

Political economists have focused on domestic politics as drivers for trade liberalisation (Mansfield \& Milner, 2012). Studies report that FTAs are guided by political motivations ranging from altering domestic coalitions against liberalisation to locking in domestic reforms, or emulating others (Aggarwal \& Shuijiro, 2006; Ravenhill, 2003). Vicard (2009) draws attention to the fact that such trade agreements not only foster trade but also promote political and institutional integration. Recent literature concurs that FTAs are a mechanism to secure domestic economic reform and serve as a way of gaining international recognition and acceptance (Aggarwal \& Lee, 2011; Aggarwal \& Urata, 2006). Free-trade agreement proliferation has also been explained as a result of policy imitation based on fear of exclusion from regional initiatives rather than of economic losses (Solis, Katada \& Stallings, 2009), and even been viewed as a reflection of geo-competition amongst actors (García, 2012). Recent work by Das, Piyadasa and Swarup (2012) points out that the lack of objectivity in different countries' trade and economic regimes makes negotiations difficult. Such factors include non-tariff barriers, restrictive practices, custom administrative practices, technical barriers to trade, rules of origin for services and investment cooperation.

\subsection{Literature on the Effects of the Proposed EU-India FTA}

Studies employ both qualitative and quantitative approaches, including CGE modelling and gravity approach, to analyse the impact of the proposed EU-India FTA. Gasoirek et al. (2007) report an 'ambiguous' welfare effect from goods sector liberalisation and this is attributed to differences in comparative advantage between the EU and India. The Government of India Report (2007) finds that India will be a net loser in the goods sector, primarily as a result of revenue losses from lower or zero tariffs, though gains are expected to be achieved through services liberalisation. Agence Europe (2007) estimates that growth of trade in goods will favour the EU, and that EU exports will grow (by 56.8 per cent), while India's exports to the EU will register moderate growth (of 18.7 per cent). Sectors such as wearing apparel and leather goods will benefit from higher exports, though export growth will be limited in manufactured items and food products. Decreux and Mitaritonna (2007) use the Modelling International Relationships in Applied General Equilibrium (MIRAGE) 
model to simulate tariff reduction (of 95 per cent) and report that EU exports to India will increase and lead to terms of trade (ToT) gains, particularly in the automobiles and machinery parts sector, which they estimate will grow by 700 per cent. For estimating the effect of services liberalisation, the MIRAGE model simulates two scenarios- 10 per cent and 25 per cent tariff cuts, respectively. Under both the scenarios, results show a positive trade impact for India such that the overall impact assessed in terms of real income is sensitive to the inclusion of services sectors for India to reap welfare benefits of the proposed FTA.

Polaski, Kumar, McDonald and Robinson (2008) employ the CGE approach and results report increased trade-higher exports to the EU (5.5 per cent) and imports from the EU (3.4 per cent). The findings show that the overall impact on India would be slightly negative, with a welfare loss (US\$250 million) and a decline in the overall real income and private household consumption. Largest increases are estimated in apparel and textiles (US\$1.9 billion), followed by 'other manufacturing', which includes leather and footwear (US\$520 million), chemicals (US\$220 million) and services (US\$230 million). India’s imports are estimated to grow by US $\$ 2.6$ billion (3.4 per cent) in manufactured goods, particularly capital goods (US\$2.1 billion). Achterbosch, Kuiper and Roza (2008) and Powell (2008) report sectoral net welfare losses for India with benefits for the EU. Benefits are limited for India due to higher Most Favoured Nation (MFN) tariffs, supply elasticities, revealed comparative advantage variations and barriers, such as 'behind-the-border' barriers to trade.

The ECORYS study (2009) uses CGE modelling and results show overall positive effects, though small in magnitude, for both the EU and India with losses in some sectors. Overall results show there are gains for India's services exports to the EU. In particular, the estimates show that India is expected to gain $€ 4.9$ billion and $€ 17.7$ billion in the short and long run, respectively, while the EU is expected to gain $€ 4.4$ billion and $€ 1.6$ billion in the short and long term, respectively. For sectors such as motor vehicles and automotives sectors, the effects on output are expected to be positive for both the EU and India, especially when dynamic FDI effects are included. The study, however, predicts a decline in Indian manufacturing sector production with negative employment changes in paper production, publishing, transport equipment, processed food and beverages and tobacco products. Investment flows as a result of the FTA, and possible future barrier reductions are estimated to generate potentially large beneficial effects for both the EU and India, estimated at $€ 17.7$ billion. The impact of the FTA on real wages (both skilled and unskilled workers) is also positive with real wages in India estimated to increase by over 1.5 per cent. 


\section{EU-India Trade Flows in Textiles, Wearing Apparel and LEATHER GOODS}

Trade data show that the EU is India's largest trading partner (in terms of both imports and exports), while India ranks as EU's eighth most important trading partner (Eurostat, 2012). Khorana et al. (2014) examine the degree of complementarity and examine intra-industry trade between the EU and India using the Grubel-Lloyd index (GII). Table 1 finds high GII across categories of manufactured goods (0.91) than non-manufactured goods (0.65), with the highest concentration in chemicals, machinery and transport equipment, while it is low for unskilled labour-intensive sectors, such as agricultural products, textiles and clothing. This finding underlies the rationale to analyse how liberalisation of the leather and textiles sectors through the proposed FTA would impact on welfare and trade.

Trade in goods between the EU and India nearly trebled during 2000-11from $€ 28.6$ billion in 2003 to $€ 79.9$ billion in 2012. In 2012, nearly 19 per cent of India's total goods exports went to the EU and 12per cent of India's total

Table 1 Grubel-Lloyd Index for Trade between the EU and India

\begin{tabular}{lccc}
\hline & \multicolumn{3}{c}{ Year } \\
\cline { 2 - 4 } Product Groups (SITC Rev 3) & 2007 & 2009 & 2011 \\
\hline 1000-Primary products & 0.65 & 0.70 & 0.75 \\
1100_Agricultural products & 0.42 & 0.40 & 0.44 \\
(food including fish and raw materials) & & & \\
1200-Fuels and mining products & 0.81 & 0.89 & 0.88 \\
2000-Manufactures & 0.91 & 0.92 & 0.94 \\
2100-Iron and steel & 0.89 & 0.73 & 0.96 \\
2200-Chemicals & 0.91 & 1.00 & 0.91 \\
2300-Other semi-manufactures & 0.69 & 0.69 & 0.69 \\
2400-Machinery and transport equipment & 0.45 & 0.59 & 0.62 \\
2410-Office and telecomm equipment & 0.41 & 0.73 & 0.81 \\
2420-Transport equipment & 0.59 & 0.97 & 1.00 \\
2430-Other machinery & 0.39 & 0.37 & 0.42 \\
2500-Textiles & 0.14 & 0.15 & 0.16 \\
2600-Clothing & 0.02 & 0.01 & 0.02 \\
2700-Other manufactures & 0.75 & 0.84 & 0.87 \\
3000-Other products & 0.55 & 0.52 & 0.66 \\
Total (all products) & 0.95 & 0.96 & 0.99 \\
\hline
\end{tabular}

Source: Khorana et al. (2014). 
Table 2 EU's Applied MFN and Preferential Tariffs for Textiles and Wearing Apparel (top 10 Indian exports)

\begin{tabular}{|c|c|c|c|}
\hline HS Code & Commodity & $\begin{array}{c}\text { MFN Applied } \\
\text { Tariffs (\%) }\end{array}$ & $\begin{array}{c}\text { Preferential } \\
\text { GSP Tariffs (\%) }\end{array}$ \\
\hline 61091000 & T-shirts, etc. of cotton & 12.00 & 9.60 \\
\hline 62063000 & $\begin{array}{l}\text { Blouses, shirts and shirt-blouses } \\
\text { of cotton }\end{array}$ & 12.00 & 9.60 \\
\hline 62052000 & Men's or boys' shirts of cotton & 12.00 & 9.60 \\
\hline 62045200 & Skirts and divided skirts of cotton & 12.00 & 9.60 \\
\hline 61112000 & Babies' garments, etc. of cotton & 12.00 & 9.60 \\
\hline 62044220 & Dresses of cotton & 12.00 & 9.60 \\
\hline 62034200 & $\begin{array}{l}\text { Trousers, bib and brace overalls, } \\
\text { breeches and shorts of cotton for } \\
\text { men and boys }\end{array}$ & 12.00 & 9.60 \\
\hline 62046200 & $\begin{array}{l}\text { Trousers, bib and brace overalls, } \\
\text { breeches and shorts of cotton }\end{array}$ & 12.00 & 9.60 \\
\hline 50072090 & $\begin{array}{l}\text { Items other than saris containing } \\
>85 \% \text { by weight of silk }\end{array}$ & 7.00 & 7.00 \\
\hline 62064000 & $\begin{array}{l}\text { Blouses, shirts, etc. of man-made } \\
\text { fibres }\end{array}$ & 12.00 & 9.60 \\
\hline
\end{tabular}

Source: DGCI\&S (2013), Government of India.

imports came from the EU. In value terms, India's exports to the EU were $€ 31.3$ billion and imports were $€ 32$ billion. ${ }^{3}$ While goods exports grew at an average rate of 14 per cent per annum, this pattern reversed in the first half of 2012 when India's overall exports to the EU fell by 11 per cent, from $€ 18.4$ billion during January-June 2012 compared to $€ 20.6$ billion during January-June 2011 (The Times of India, 2012). A detailed analysis of India's trade on the basis of Harmonised System (HS) 2-digit data shows that textiles, wearing apparel and leather products (HS 52,61, 62, 63, 64 and 42, respectively) constitute nearly a quarter of India's total exports to the EU. In particular, the compound annual growth of wearing apparel has increased sharply from 3.7per cent in early 2000 to 15.2 per cent following the elimination of Multi-Fibre Agreement (MFA) quantitative restrictions and quotas in 2005, though this trend has not been sustained and wearing apparel exports have registered a decline of 19.46 per cent on an year-on-year basis in the first half of 2012 (The Times of India, 2012). Table 2 presents top 10 tariff lines within textiles and wearing apparel showing

\footnotetext{
${ }^{3}$ Top export destinations within the EU were Germany (26 per cent) followed by the United Kingdom (16 per cent) and Belgium (13 per cent).
} 
applied EU's MFN and preferential Generalised Scheme of Preferences (GSP) ${ }^{4}$ tariffs on Indian exports.

Until 1 January 2014, Indian exports enjoyed preferential tariffs under the GSP framework on textiles but this sector has now been graduated out of the GSP scheme for India (EC Regulation 978/2012). If tariffs on wearing apparel were to enter the EU at zero tariffs under the FTA, this will allow Indian-made apparels' market accessible in the EU and make it competitive compared to exports from Bangladesh, Vietnam, Mexico and Pakistan. Under the present regime, least developed countries exports of textiles and wearing apparel enjoy duty-free access under 'Everything but Arms' scheme (EC Regulation 416/2001) making Bangladeshi exports hugely competitive. Zero tariffs will also enable Indian exporters to be competitive vis-à-vis Chinese wearing apparel (Business Standard, 2012). Thus, Indian apparel exports which have of late suffered from rising costs and international economic downturn will be competitive (compared to Bangladesh, Pakistan, Indonesia, Vietnam, Turkey and Mexico).

In 2011-12, Eurostat data show that EU's imports of leather products from India were 65.48 per cent, with Germany as the largest market for Indian leather and leather products (12.52 per cent), followed by UK (11.98 per cent), Italy (8.81 per cent), France (5.86 per cent), Spain (5.52 per cent), the Netherlands (3.95 per cent), Belgium (1.90 per cent) and Denmark (1.71 per cent). Trade data show that leather shoes (64035111) and accessories (42022190 and 42022110) are main exports, with nearly half of the total leather exports concentrated under 10 top eight-digit lines. Further analysis reveals that 30 per cent of total leather products exported by India access the EU under the GSP scheme. Table 3 lists the top 10 tariff lines within leather, and the prevalent applied MFN and preferential tariffs on this product group.

Analysis reveals that 165 tariff lines are notified on leather and leather products (HS 41, 42 and 63) under the EU tariff schedule. Of this, 136 tariff lines enjoy preferential tariffs ( 3.5 percentage point reduction at the ad valorem rate) under the GSP scheme. The remaining 29 are non-sensitive and products come into the EU under zero tariffs. This suggests that nearly one-fourth of the total tariff lines notified under leather products enjoy duty-free access. Thus, leather accessories and garments (HS 42), such as leather handbags, jackets and saddles, that are currently allowed into the EU at zero tariffs under the

\footnotetext{
${ }^{4} \mathrm{GSP}$ is a non-reciprocal, non-discriminatory system of preferences granted by developed countries in favour of the developing countries, including special measures in favour of the least advanced among developing countries. The EU GSP, which was initiated in 1971, has been modified on several occasions and the EU adopted a new scheme in 2009-11 which applies to 176 developing countries, including India.
} 
Table 3 Applied MFN and Preferential Tariffs of Top 10 Leather Products Exported to the EU

\begin{tabular}{llcc}
\hline HS Code & Products & $\begin{array}{c}\text { MFN Applied } \\
\text { Rate (\%) }\end{array}$ & $\begin{array}{c}\text { Tariff Preference } \\
\text { Rate (GSP) (\%) }\end{array}$ \\
\hline 64035111 & $\begin{array}{l}\text { Ankle covered all-leather shoes } \\
\text { for men }\end{array}$ & 8.00 & 4.50 \\
42022190 & Other leather handbags & 3.00 & 0.00 \\
42022110 & Handbags of leather for ladies & 3.00 & 0.00 \\
42023120 & Wallets and purses of leather & 3.00 & 0.00 \\
42031010 & Jackets and jerseys & 4.00 & 0.00 \\
64031990 & Others & 8.00 & 4.50 \\
64032029 & Other footwear with all leather, & 8.00 & 4.50 \\
& open toed & & 4.50 \\
64039110 & Leather boots and other footwear & 8.00 & \\
& with rubber sole & & 0.00 \\
62010000 & Saddlery and harness for animals & 2.70 & 4.50 \\
\hline
\end{tabular}

Source: DGCI\&S (2013), Government of India.

existing GSP framework, might not benefit from further tariff reduction under the FTA scenario.

\section{GTAP Model: Theoretical Framework}

This article employs CGE modelling approach, developed by Hertel (1997), to analyse economic effects of the proposed EU-India FTA. The CGE approach analyses aggregate welfare and distributional impacts of policies whose effects may be transmitted through multiple markets (Perry, Whalley \& McMahon, 2001), international trade (Harrison, Rutherford \& Tarr, 1997) and also assesses the impact of environmental regulation (Goulder, 2002). Computable general equilibrium models are an ex-ante analysis of trade policies and agreements capturing economy-wide impact of policy shocks associated with trade openness; they enable a quantitative assessment of the direct and indirect effects of changes in trade policy and other policy interventions while taking overall market relationships into account. The underlying theory of CGE is grounded in behavioural equations with the model assuming full employment and perfect competition in all markets such that demand equals supply and markets are self-clearing so that all producers receive the same marginal cost. Other assumptions include zero profits implying revenues must be exhausted through expenditure on domestic and imported intermediate inputs. 
The GTAP model has a single representative household which receives factor income and maximises utility subject to the expenditure constraint through the Constant Difference of Elasticity (CDS) and Constant Elasticity of Substitution (CES). Regional households allocate expenditure over private, government and savings according to Cobb-Douglas utility function and each component of the final demand is a constant share of total regional income. These goods represent CES combinations for domestic and imported goods (with CES aggregation of imports for each region) and the consumer demand elasticities draw on the work by Reimer and Hertel (2004). The model provides a basis for differentiation between products by countries and regions (Armington assumption), allows distinguishing between trade flows by country/region or destination and on the basis of agents, that is, intermediate demand, final demand by households, government and investment. Import shares are determined by the relative prices and substitution elasticities between domestic and imported commodities.

The GTAP model has a nested production function which minimises total costs through substitution of inputs (primary and intermediate). At the first level, the intermediate input bundles and primary-factor bundles are used in fixed proportions according to a Leontief function. At the second level, intermediate input bundles are formed as combinations of imported bundles and domestic goods, and primary-factor bundles are obtained according to the CES form. At the third level, imported bundles are formed as CES composites of imported goods with the same name from each region. The parameters of factor substitution elasticities, factor transformation elasticities and investment parameters are based on Hertel, et al. (2004).

The government has a fixed share of aggregate expenditure in each region which is allocated across commodities by a Cobb-Douglas distribution. The allocation of total expenditure on each good to domestically produced and imported versions is based on the same nesting scheme used to allocate total household expenditure on each good. The standard GTAP closure takes factor endowments, technology and tax and subsidy rates as exogenous variables. Investment is financed by a global pool of savings with each region contributing a fixed share to this pool. Savings are allocated to regions either in a fixed proportion or according to the relevant rates of return.

This article employs GTAP database 7 which originally includes 57 commodities and 113 regions with 2004 as the base year (Narayanan et al, 2008). We aggregate the GTAP product groups into 11 sectors; the details of these are presented in Table 4.

Table 5 presents an overview of the regional aggregation, which includes India and $\mathrm{EU}$ as well as other countries aggregated by regions. 
12 Margin—The Journal of Applied Economic Research 11:1 (2016): 1-22

Table 4 Product Groups

\begin{tabular}{ll}
\hline Product Groups & Description \\
\hline Agrifood & Grains and crops \\
Fibres & Fibres \\
Extraction & Mining and extraction \\
Tex & Textiles \\
Wap & Clothing \\
Lea & Leather \\
LightMnfc & Light manufacturing \\
HeavyMnfc & Heavy manufacturing \\
Util_Cons & Utilities and construction \\
TransComm & Transport and communication \\
OthServices & Other services \\
\hline
\end{tabular}

Source: Based on GTAP database.

Table 5 Regional Aggregation

\begin{tabular}{ll}
\hline Regions Used for Analysis & Regional Aggregation Description \\
\hline China & China \\
EastAsia & East Asia \\
SEAsia & Southeast Asia \\
India & India \\
XSASIA & South Asia \\
USACAN & USA and Canada \\
LatinAmer & Latin America \\
EU_27 & European Union 27 \\
MENA & Middle East and North Africa \\
SSA & Sub-Saharan Africa \\
Rest of World & Rest of the World \\
\hline
\end{tabular}

Source: Based on GTAP database.

The GTAP database sources include individual countries' input-output tables, global trade information and aggregate bilateral trade statistics from UN trade statistics. This is supplemented by data from the International Monetary Fund (IMF), Food and Agriculture Organization (FAO) and the World Bank. Tariff and protection data are taken from the MacMap database at the HS-6 level, which is in turn aggregated using trade weights compiled from COMTRADE database.

\section{Simulations and Results}

The analysis is structured around a set of scenarios that recognise the importance of textiles, apparel and leather goods in India's trade with the EU that these 
product groups constitute nearly a third of the total Indian exports to the EU (Eurostat, 2012; Khorana \& Soo, 2013). The model simulations examine product-related interests, conditional to India and EU opening up the market, through the following scenarios:

1. Scenario 1: Zero tariffs on all products and immediate implementation of the proposed EU-India FTA. This scenario models the effect of 100 per cent tariff elimination by EU and India on all goods, so that all bilateral tariffs are completely eliminated as soon as the FTA comes into force.

2. Scenario 2: Sector-specific tariff elimination, that is, 100 per cent tariff elimination on textiles, wearing apparel and leather products including footwear (Texlea) by the EU and India. This scenario also simulates the elimination of all export tax equivalents of MFA quotas in the GTAP database.

To account for unemployment in India and other developing countries, the model assumes endogenous unskilled labour supply and exogenous wages.

To examine the macroeconomic effects of tariff elimination under the proposed FTA, as well as trade creation and diversion effects, we measured equivalent variation $(\mathrm{EV})$, which is a measure of what change in income would be equivalent to the proposed policy change. The focus is mainly on allocative efficiency changes arising from any improvements in inter-sectoral resource allocation, ToT effect and changes in savings-investment balance. ${ }^{5}$ Table 6 presents welfare effects in EV terms from: (i) 100 per cent tariff elimination on all goods under the FTA (scenario 1) and (ii) 100 per cent tariff elimination on selected products, such as textiles, apparel and leather products (scenario 2).

The analysis shows that some sectors gain, while others lose from liberalisation under the FTA. Simulation results for scenario 1, that models full liberalisation of all products, yield positive welfare effects for both the EU and India. Countries and regions outside the FTA report welfare losses, highest being in MENA (US\$785) followed by SSA (US\$326). This suggests EU-India FTA could have trade diversionary effects for other countries. The decomposition of welfare effects reveals that gains for the EU (US\$2,964 million) are mainly driven by positive ToT and allocative efficiency effects. The breakdown of allocative efficiency by factors and commodities highlights heavy manufacturing industry and extraction industries as product groups that gain from the proposed FTA.

\footnotetext{
${ }^{5}$ The allocative efficiency gains accrue from optimum allocation of resources. The terms of trade effect are an indicative summary measure of change in ratio of prices received for exports and paid for imports.
} 
14 Margin-The Journal of Applied Economic Research $11: 1$ (2016): 1-22

Table 6 Welfare Effects under Scenarios 1 and 2 (in million US\$)

\begin{tabular}{|c|c|c|c|c|c|}
\hline & $\begin{array}{c}\text { Allocative } \\
\text { Efficiency } \\
\text { Effect }\end{array}$ & $\begin{array}{c}\text { Endowment } \\
\text { Effect }\end{array}$ & $\begin{array}{l}\text { Terms of } \\
\text { Trade Effect }\end{array}$ & $\begin{array}{l}\text { Investment- } \\
\text { Savings Effect }\end{array}$ & Total \\
\hline \multicolumn{6}{|c|}{ Scenario 1} \\
\hline China & -36.6 & -44.8 & -141.9 & 53.3 & -169.9 \\
\hline EastAsia & -12.4 & 0 & 56.8 & 78.4 & 122.9 \\
\hline SEAsia & -18.4 & 8.4 & -224.5 & 46.6 & -187.9 \\
\hline India & -272 & $3,125.4$ & -685.8 & -243.9 & $1,936.7$ \\
\hline XSASIA & -21.4 & -18.2 & -5.6 & -28.4 & -73.6 \\
\hline USACAN & 4.7 & 0 & 184.5 & -89.1 & 100 \\
\hline LatinAmer & 21.9 & 20.9 & -138.4 & 14.9 & -80.7 \\
\hline EU_27 & 511.7 & 0 & $2,399.1$ & 53.3 & $2,964.1$ \\
\hline MENA & -40.6 & 0 & -830.6 & 86.1 & -785.1 \\
\hline SSA & -24.6 & -13.3 & -295.8 & 7.7 & -325.9 \\
\hline Rest of World & 472.4 & 0 & -324 & 21.1 & 169.4 \\
\hline \multicolumn{6}{|c|}{ Scenario 2} \\
\hline China & -14.2 & -77.3 & -108 & -6.1 & -205.7 \\
\hline EastAsia & 0.5 & 0 & -47.5 & -16.9 & -63.9 \\
\hline SEAsia & -3.9 & -27.9 & -26.7 & -3.5 & -62.2 \\
\hline India & 287.4 & $1,111.5$ & 634.2 & 114.8 & $2,148.1$ \\
\hline XSASIA & -18.4 & -42.2 & -41.3 & -6.9 & -108.9 \\
\hline USACAN & -2.2 & 0 & -28.4 & -24.3 & -54.9 \\
\hline LatinAmer & -7 & -6.4 & 0.3 & -7.4 & -20.4 \\
\hline EU_27 & -48.5 & 0 & -329.2 & -34.4 & -412.1 \\
\hline MENA & 8.6 & 0 & -38.3 & -6.4 & -36.1 \\
\hline SSA & -11.1 & -4.5 & -7.9 & -1.8 & -25.2 \\
\hline Rest of World & 1.4 & 0 & -9.3 & -7.4 & -15.3 \\
\hline
\end{tabular}

Source: Model simulations.

Gains are attributed to zero tariffs on these products because of high, 14.4 per cent, average applied MFN tariff notified by India to the WTO, ${ }^{6}$ with 34.7 per cent and 10.5 per cent MFN tariffs on agricultural and industrial products, respectively. An analysis of the disposition of imports by India reveals a higher share for firms ( 55.1 per cent) followed by households ( 47.5 per cent) indicating higher exports by competitive EU firms under the liberalised scenario.

Further under full liberalisation, India faces ToT losses (US\$686 million) from trade diversion which is counterbalanced by a large and positive endowment

\footnotetext{
${ }^{6}$ The tariff structure notified by India to the WTO provides protection to agriculture (mainly beverages and tobacco followed by coffee, tea and oilseeds, fats and oils), automobiles and textiles and clothing sectors.
} 
effect (US\$3125 million). Sector-level analysis shows that ToT losses are primarily driven by extraction and capital-intensive manufacturing sectors. These sectors are protected and higher imports together with ToT losses suggest possible trade diversion.

Scenario 2 simulates selective sector liberalisation of textiles, apparel and leather that reports gains for India, but losses for the EU. Detailed country analysis reveals that China and South Asian countries, such as Bangladesh and Pakistan, lose from trade diversion effects of selective liberalisation under the FTA. An explanation is that zero tariffs post-FTA make Indian exports competitive, given that MFN tariff levied by the EU pre-FTA is 7.2 per cent (ad valorem equivalent), thus enabling Indian exporters to benefit by the preference margin. Further, positive ToT effects under selective liberalisation also lead to higher labour demand by textiles and leather, transport and construction sectors. Thus, gains for India drive resource allocation and endowment effect resulting from higher demand of unskilled labour.

Table 7 presents sectoral output effects from liberalisation, that is, which sectors gain or lose under the proposed FTA.

Simulation results show that there is no large change in EU output but this is not the case with India where output of apparel, followed by leather, textiles and fibres increases. The output in textiles, apparel and leather sector, however, varies under both scenarios with larger increase in scenario 1 (54 per cent) compared to scenario 2 ( 38 per cent). The increased output is explained by

Table 7 Output Effect (initial value and \% change)

\begin{tabular}{|c|c|c|c|c|c|c|}
\hline \multirow[b]{2}{*}{ Sector } & \multicolumn{2}{|c|}{$\begin{array}{c}\text { Initial Value } \\
\text { (in millions of US\$) }\end{array}$} & \multicolumn{2}{|c|}{$\begin{array}{l}\text { Scenario } 1 \\
\text { (\% change) }\end{array}$} & \multicolumn{2}{|c|}{$\begin{array}{l}\text { Scenario } 2 \\
\text { (\% change) }\end{array}$} \\
\hline & India & $E U 27$ & India & $E U 27$ & India & EU27 \\
\hline Agrifood & 242,062 & $1,822,872$ & 0.1 & 0 & 0 & 0 \\
\hline Fibres & 10,661 & 8,785 & 4.8 & 0 & 3.4 & 0 \\
\hline Extraction & 37,693 & 203,651 & -1.4 & 1 & -0.5 & 0 \\
\hline Tex & 45,380 & 246,950 & 6.5 & -0.9 & 4.7 & -0.5 \\
\hline Wap & 7,555 & 262,003 & 30.2 & -0.7 & 24.9 & -0.4 \\
\hline Lea & 5,459 & 104,485 & 10 & -0.5 & 5.9 & -0.1 \\
\hline LightMnfc & 96,367 & $2,801,265$ & 1 & 0 & -0.8 & 0 \\
\hline HeavyMnfc & 216,488 & $4,264,192$ & 0.7 & 0.1 & -0.6 & 0 \\
\hline Util_Cons & 142478 & $1,754,420$ & 1.5 & 0 & 0.3 & 0 \\
\hline TransComm & 210,355 & $4,525,418$ & 0.8 & 0 & 0.4 & 0 \\
\hline OthServices & 184,524 & $8,609,255$ & -0.3 & 0 & -0.1 & 0 \\
\hline
\end{tabular}

Source: Model simulations. 
Table 8 Change in Factors and Factor Prices (\% terms)

\begin{tabular}{|c|c|c|c|c|}
\hline \multirow[b]{2}{*}{ Factor change (\%) } & \multicolumn{2}{|c|}{ Scenario 1} & \multicolumn{2}{|c|}{ Scenario 2} \\
\hline & India & $E U \_27$ & India & $E U \_27$ \\
\hline $\begin{array}{l}\text { UnSkLab (\% } \\
\text { change) }\end{array}$ & 1.6 & 0 & 0.6 & 0 \\
\hline $\begin{array}{l}\text { UnSkLab (change } \\
\text { in millions of US\$) }\end{array}$ & 3091.12 & 0 & 1159.17 & 0 \\
\hline \multirow{2}{*}{$\begin{array}{l}\text { Change in factor } \\
\text { prices (\%) }\end{array}$} & \multicolumn{2}{|c|}{ Scenario 1} & \multicolumn{2}{|c|}{ Scenario 2} \\
\hline & India & $E U \_27$ & India & $E U \_27$ \\
\hline Land & 1.2 & 0 & 1.2 & 0 \\
\hline UnSkLab & -0.2 & 0.1 & 0.7 & 0 \\
\hline SkLab & 0.8 & 0.1 & 1 & 0 \\
\hline Capital & 0.9 & 0.1 & 0.9 & 0 \\
\hline
\end{tabular}

Source: Model simulations.

expansion of fibre trade under the FTA scenario. Also, EU's output of capital intensive and manufactures goes up under full liberalisation. However, India's output of textiles, apparel and leather increases substantially under scenario 2, which when interpreted in light of low factor prices in India hints at possible relocation of textile manufacturing from the EU, possibly from Eastern Europe into India as EU firms stand to benefit from low production costs.

Table 8 presents the results on changes in factor demand and prices when there is full liberalisation of all sectors (scenario 1) and sector-specific liberalisation (scenario 2) under the proposed FTA. Simulation results show that the demand for factors of production, in particular for unskilled labour (since other factors are fixed), increases as output increases. In this case, the transmission mechanism is through export and import prices that in turn impact on domestic prices. Rising demand for unskilled labour leads to an initial upward pressure on wages in scenario 2 which in turn drives labour supply into textile, apparel and leather industry.

Under scenario 1, factor prices in India show a tendency to rise (except unskilled labour). Further, an increase in land price complemented with increase in capital and skilled wages leads to an upward pressure on wages. In scenario 2 , when textiles, apparel and leather products are selectively liberalised under the FTA, demand for unskilled labour increases, though to a lesser extent, and remuneration for factors of production, that is, land, labour and capital, shows an upward trend. In combination with a minor increase in skilled wages and constant capital price, the signs of economic restructuring away from skilled manufacturing to labour-intensive production are evident. Further, as 
economies of scale are enabled by intra-industry trade, production efficiency is also likely to be improved. In static terms, tariff reduction and liberalisation through the FTA can be employed as a means to expand manufacturing by Indian firms through a reallocation of productive resources, that is, capital and labour, encouraging Indian firms to invest in capital saving technique, which will increase the labour-capital output with positive employment effects. Among explicit arguments for pushing FTA talks between the EU and India is the potential to gain from external and internal economies of scale, and that it is likely to impact on production patterns in both India and the EU, through specialisation. Gains from internal economies of scale are likely to be determined by firms' interaction and their linkages within an industry. External economies of scale manifesting in intra-industry trade, however, are likely to emanate from inter-industry externalities at the national level, although these will again depend on differences among industry groups across the trading partners.

Given that the simulations project an increase in exports of specific product groups liberalised and in light of higher demand for labour (unskilled and skilled) as well as capital, it is likely that production may be forced to move to the lower end of the value chain under the FTA. This implies that the FTA might potentially shift Indian apparel production to specialise in low-value production. In light of the striking benefits that are expected to accrue to textiles, apparel and utilities and construction sectors, it is likely that these sectors will benefit from higher investments and technology inflows, which in turn will enable Indian producers to be competitive.

\section{Conclusion and the Way Forward}

Tariff elimination under scenario 1 under the FTA will enhance India's exports of textiles, wearing apparel and footwear to the EU though at the cost of trade diversionary effects for other countries, with positive welfare and endowment effects. Factor prices change indicating that the current pattern of trade could change with India specialising in low-value production. Terms of trade losses for India follow from higher imports of extraction and capital-intensive manufacturing from the EU after the FTA. Scenario 2, which is sectoral liberalisation of textiles, apparel and leather products, shows gain for India from the endowment effect and resource allocation, but losses for the EU. Increased apparel sector output leads to higher demand for fibres, and suggests the possibility that EU textile manufacturing could possibly locate to India to benefit from low production costs under the FTA. This is reflected in higher demand for unskilled labour under the FTA. In combination with a minor 
increase in skilled wages and constant capital price, tariff elimination on Indian textile under the FTA could potentially change production patterns. Further, higher output at low prices will make Indian products hugely competitive in comparison to Indonesia, Bangladesh, Vietnam, Turkey and Mexico. Thus, India must focus on negotiating tariff elimination on textiles, wearing apparel and footwear under the FTA framework. But the question is why should the EU allow selective liberalisation and what are the gains in this? The way forward for India would be to consider accepting some EU demands, such as selective liberalisation in services sector mainly in legal and accounting services, banking and insurance, which have not been examined in this article. Modelling nontariff barriers in services trade is an enormous task in itself and may be done in a different in-depth study in the future. Such a study could throw light on the gains and losses that may arise from FTA in services sectors.

Since the launch of negotiations in 2007, not much progress has been made. A concerted effort is the call of the hour if the EU and India want to push this trade deal through. The new Indian government in power has a pro-market orientation blended with a nationalistic approach as inferred from the recent tough stand in the WTO on food security. Thus, a rethink of the negotiating strategy might just be what is needed to build a higher level of enthusiasm to restart FTA talks.

\section{References}

Achterbosch, T., Kuiper, M., \& Roza, P. (2008). EU-India free trade agreement: A quantitative assessment. Report no. 2008-059, Project code 20824. The Hague: LEI Wageningen.

Agence Europe. (2007). Council's green light to launch of negotiations for bilateral free trade agreements with ASEAN, South Korea and India. Retrieved 15 November 2016, from www. ciaonet.org/pbei/oxfam/0003418/f_0003418_2529.pdf

Aggarwal, V., \& Lee, S. (Eds). (2011). Trade policy in the Asia Pacific: The role of ideas, interests and domestic institutions. New York: Springer.

Aggarwal, V.K. and Shujiro, U., 2006. Bilateral Trade Agreements in the Asia-Pacific. London: Routledge.

Aggarwal, V.K. and Urata, S. (2006). Bilateral Trade Agreements in the Asia Pacific: Origins, Evolution and Implications, Abingdon: Routledge.

Anderson, J., Yotov, Y.V. (2011). "Terms of Trade and Global Efficiency Effects of Free Trade Agreements, 1990-2002.” NBER Working Papers 17003. Cambridge: National Bureau of Economic Research.

Baier, S., \& Bergstrand, J. (2007). Do free trade agreements actually increase members' international trade? Journal of International Economics, 71(1), 72-95.

Baldwin, R. (1993) 'A Domino Theory of Regionalism'. Working Paper 857. London: Centre for Economic Policy Research.

. (1995). A domino theory of regionalism. In R. Baldwin, P. Haarparanta \& J. Kianden (Eds), Expanding membership of European Union. Cambridge: Cambridge University Press. 
- (2002). The causes of regionalism. The World Economy, 20(7), 865-88.

. (2006). Multilateralising regionalism: Spaghetti bowls as building blocks on the path to global free trade. The World Economy, 29(2), 1451-518.

- (2008). Managing the noodle bowl: The fragility of East Asian regionalism. Singapore Economic Review, 53(3), 449-79.

. (2011). Trade and industrialisation after globalisation's 2 nd unbundling: How building and joining a supply chain are different and why it matters. NBER working paper 17766. Cambridge: National Bureau of Economic Research.

- (2013). Lessons from the European spaghetti bowl. ADBI working paper 418. Tokyo: Asian Development Bank Institute.

Baldwin, R., \& Jaimovich, D. (2012). Are free trade agreements contagious? Journal of International Economics, 88(1), 1-16.

Baldwin, R., \& Venables, A. (1995). Regional economic integration. In G. Grossman \& K. Rogoff (Eds), Handbook of international economics. Amsterdam: Elsevier Science Publishers.

Bhagwati, J. (1998). Trading preferentially: Theory and policy. Economic Journal, 108(449), $1128-48$.

Bhagwati, J., \& Panagariya, A. (1996). The economics of preferential trade agreements. Cambridge, MA: The AEI Press.

Brown, D.K., Deardorff, A.V., \& Stern, R.M. (1994). A North American free trade agreement: Analytical issues and a computational assessment. The World Economy, 15(1), 11-30.

Business Standard. (2012). FTA with EU to benefit textile exports. Retrieved 4 June 2015, from http://www.business-standard.com/india/news/ftaeu-soon-to-benefit-textileexports/480043/

Cernat, L. (2003). Assessing regional trade agreements: Are South-South RTAs more trade diverting? Geneva: UNCTAD, mimeo.

Coe, D., \& Hoffmaister, A. (1999). North-South trade: Is Africa unusual? Journal of African Economies, 8(2), 228-56.

Dai, M., Yotov, Y.V., \& Zylkin, T. (2014). On the trade-diversion effects of free trade agreements. Economics Letters, 122(2), 321-325

Das, R.U., Piyadasa, E., \& Swarup, A. (2012). Regional trade and economic integration: Analytical insights and policy options (pp. 1-234). Singapore and NJ: World Scientific.

Decreux, Y., \& Mitaritonna, C. (2007). Economic impact of a potential free trade agreement between the European Union and India. Report by CEPII/CEMIN to the DG trade of the European Commission, trade specific contract no: SI2.434.087. Retrieved 4 June 2015, from http://trade.ec.europa.eu/doclib/html/134682.htm

Dent, C. (2003). Networking the region? The emergence and impact of Asia-Pacific bilateral free trade agreement projects. Pacific Review, 16(1), 1-28.

ECORYS. (2009). Trade sustainability impact assessment for the FTA between the EU and the Republic of India. Report for DG trade in the European Commission, reference no. TRADE07/C1/C01 - Lot 1. Luxembourg: Publications Office of the European Union.

Ethier, W. (1998). The new regionalism. The Economic Journal, 108(449), 1149-61.

European Commission. (2010). Growth, jobs and trade, COM 216. Luxembourg: Publications Office of the European Union

- (2015). Report from the commission to the European council trade and investment barriers report, COM 127 final. Retrieved from http://trade.ec.europa.eu/doclib/docs/2015/ march/tradoc_153259.pdf 
Eurostat. (2012). News release. Brussels.

Frankel, J. (1997). Regional trading blocks in the world economic system. Washington, DC: Institute for International Economics.

Frankel, J., Stein, E., \& Wei, S. (1995). Trading blocs and the Americas: The natural, the unnatural and the supernatural. Journal of Development Economics, 47(1), 61-96.

Frankel, J., \& Wei, S.J. (1997). Regionalization of world trade and currencies: Economic and politics', regionalisation of the world economy. Chicago: University of Chicago Press.

Freund, C. L., \& Ornelas, E. (2010). Regional trade agreements. World Bank Policy Research Working Paper 5314. Washington, DC: World Bank.

García, M. (2012). Competitive fears: The EU, USA and the free trade agreements in East Asia. European Union, Foreign Affairs Review, 2(1), 59-71.

Gasiorek, M., Holmes, P., Robinson, S., Rollo, J. \& Shingal, A. (2007). Qualitative analysis of a potential free trade agreement between the European Union and India. Executive Summary Report to DG Trade of the European Commission, Sussex, University of Sussex, Centre for the Analysis of Regional Integration at Sussex and CUTS International, Jaipur. Retrieved 4 June 2015, from http://www.cuts_citee.org/EUIndia_RTA.htm

Goulder, L. (2002). Environmental policy making in economies with prior tax distortions. Northampton, MA: Edward Elgar.

Government of India. (2007). 'Exploring New Regionalism: The EU, India and Beyond'. Proceedings from the conference organised by CENTAD, 30 October-1 November.

Grossman, G., \& Helpman, E. (1991). Innovation and growth in the global economy. Cambridge, MA: MIT Press.

Harrison, G.W., Rutherford, T.F., \& Tarr, D.G. (1997). Quantifying the Uruguay round. Economic Journal, 107(444), 1405-30.

Helpman, E., Melitz, M., \& Rubinstein, Y. (2008). Estimating trade flows: Trading partners and trading volumes. The Quarterly Journal of Economics, 123(2): 441-487.

Hertel, T. (Ed.). (1997). Global trade analysis: Modelling and application. Cambridge: Cambridge University Press.

Hertel, T., Hummels, D., Ivanic, M., \& Keeney, R. (2004). How confident can we be in CGEbased assessments of free trade agreements? GTAP working paper no. 26. Indianapolis, US: Centre for Global Trade Analysis.

Keller, W. (1998). Are international R\&D spillovers trade-related? Analysing spillovers among randomly matched trade partners. European Economic Review, 42(8), 1469-81.

Khorana, S., \& Asthana, A. (2014). EU's FTA negotiations with India: The question of liberalisation of public procurement. Asia Europe Journal, 12(3), 251-63. doi:10.1007/ s10308-014-0369-7

Khorana, S., \& Garcia, M. (2013). EU-India free trade agreement: One step forward, one back? Journal of Common Market Studies, 41(3), 274-300.

Khorana, S. and Garcia, M., (2014). Procurement Liberalization Diffusion in EU Agreements:Signalling Stewardship? Journal of World Trade, 48(3), 481-500.

Khorana, S., Kerr, W.A., \& Perdikis, N. (2014). Global economies of scale in the EU-India trade agreement: Are they the key to a return to economic growth? Asia Europe Journal, 13, 41-55. doi:10.1007/s10308-014-0404-8

Khorana, S., Perdikis, N. \& D.K. Das (2008), Convergence between the EU and India: Foreign and Commonwealth Office. New Delhi: British High Commission.

Khorana, S., \& Perdikis, N. (2010). EU-India free trade agreement: Deal or no deal. South Asia Economic Journal, 11(2), 182-206. 
Khorana, S., Soo, K., T. (2013). Exporter's perceptions to obstacles faced in the EU: evidence from Indian textiles and leather goods firms. International Journal of Indian Culture and Business Management, 7(2), 261-277.

Kehoe, P.J., \& Kehoe, T.J. (1994). Capturing NAFTA's impact with applied general equilibrium models. Federal Reserve Bank of Minneapolis. Quarterly Review-Federal Reserve Bank of Minneapolis, 18(2), 17.

Krugman, P. (1993). Regionalism versus multilateralism: Analytical notes. In J. de Melo \& A. Panagariya (Eds), New dimensions in regional integration. Cambridge: Cambridge University Press.

Lee, J.W., \& Shin, K. (2006). Does regionalism lead to more global trade integration in East Asia? The North American Journal of Economics and Finance, 17(3), 283-301.

Lipsey, R.G. (1957). The theory of customs unions; trade diversion and welfare. Economica, $24,40-46$.

Magee, C.S. (2003). Endogenous preferential trade agreements: An empirical analysis. Contributions in Economic Analysis \& Policy, 2(1).

Magee, C. (2008). New measures of trade creation and trade diversion. Journal of International Economics, 75(3), 340-62.

Magee, C. S. (2016). Trade creation, trade diversion, and the general equilibrium effects of regional trade agreements: a study of the European Community-Turkey customs union. Review of World Economics, 152(2), 383-399

Mansfield, E., \& Milner, H. (2012). Votes, vetoes and the political economy of preferential trade agreements. Princeton: Princeton University Press.

Meade, J. (1955). The theory of customs union. Amsterdam: North-Holland.

Narayanan, G. Badri, \& Walmsley, Terrie L. (Eds). (2008). Global trade assistance and production: The GTAP 7 database. Center for Global Trade Analysis, Purdue University.

Ng, T.H., \& Yarcia, D.L. (July 2014). Has regional integration led to greater risk-sharing in Asia? ADB working paper series on regional economic integration, no. 135. Manila: Asian Development Bank.

Panagariya, A. (1996). The free trade area of the Americas: Good for Latin America? The World Economy, 19(5), 485-515.

- (2000). Preferential trade liberalization: Traditional theory and new developments. Journal of Economic Literature, 38(2), 287-331.

Perry, G., Whalley, J., \& McMahon, G. (2001). Fiscal reform and structural change in developing countries. New York: Palgrave-Macmillan.

Polaski, S.A., Kumar, G., McDonald, S., \& Robinson, S. (2008). India's trade policy choices. Washington, DC: Carnegie Endowment for International Peace. Retrieved 4 September 2014, from http://www.carnegieendowment.org/files/india\%27s_trade_policy_choices_ final.pdf

Pomfret, R. (1988). Unequal Trade: The Economics of Discriminatory International Trade Policies. Oxford, Blackwell.

Powell, S. (2008). The EU-FTA: Initial observations from a development perspective (pp. 1-21). London: Traidcraft Exchange. Retrieved 4 September 2014, from http://www.indianet. nl/pdf/EU-IndiaFTAInitialObservations.pdf

Ravenhill, J. (2003). The New Bilateralism in the Asia Pacific. Third World Quarterly, 24(2), 299-317.

Reimer, J., \& Hertel, T. (2004). International cross section estimates of demand for use in the GTAP model. GTAP technical paper no. 23. US: Centre for Global Trade Analysis. 
Robinson, S., \& Thierfelder, K. (2002). Trade liberalisation and regional integration: The search for large numbers. Australian Journal of Agricultural and Resource Economics, 46(4), 585-604.

Solis, M., Katada, S., \& Stallings, B. (Eds). (2009). Competitive regionalism: FTA diffusion in the Pacific Rim. Palgrave Macmillan.

Srinivasan, T.N. (1998). Trade and human rights. In A. Deardoff \& R. Stein (eds), Constituent interests and US trade policies, 225-53. Ann Arbor: University of Michigan Press.

Summers, L. (1991). Regionalism and world trading system. In Policy implications of trade and currency-Proceedings of symposium sponsored by the Federal Reserve Bank of Kansas City, Wyoming, USA.

The Times of India. (2012, September). EU-India trade drops. Retrieved 4 June 2015, from http://articles.timesofindia.indiatimes.com/2012-09-19/india-business/33951515_1_euindia-trade-eu-exports-cent

Vicard, V. (2009). On trade creation and regional trade agreements: Does depth matter? Review of World Economy, 145(2), 167-87.

Viner, J. (1950). The customs union issue. In J. Bhagwati et al. (Eds), Trading blocks alternative approaches to analysing preferential trade agreements. Cambridge: MIT Press.

Wei, S. \& Frankel, J. (2005). "Slow Passthrough Around the World: A New Import for Developing Countries?” NBER Working Paper No. 11199. Cambridge, National Bureau of Economic Research.

Wannacott, Ronald J. (1990). U.S. Hub-and-Spoke Bilaterals and the Multilateral Trading System. Commentary (whole issue, October). Toronto: C.D. Howe Institute.

Wonnacott, P., \& Lutz, M. (1989). Is there a case for free trade areas? In J.J. Schott (Ed.), Free trade areas and U.S. trade policy (pp. 59-84). Washington, DC: Institute for International Economics.

World Bank, (2000). World Bank, 2000. World Development Indicators. World Bank, Washington, DC. 